\title{
The South China Sea Dispute and Regional Maritime Security: Indonesia's Perspective
}

\author{
Marsetio $^{1}$, Amarulla Octavian ${ }^{1}$, Rudiyanto ${ }^{2}$, Janet Dyah Ekawati Gibson ${ }^{1}$, Kazan \\ Gunawan $^{3}$ and Rajab Ritonga ${ }^{4 *}$ \\ ${ }^{1}$ Indonesia Defense University, Bogor, West Java, Indonesia \\ ${ }^{2}$ Biro Klasifikasi Indonesia, Tanjung Priok, Jakarta, Indonesia \\ ${ }^{3}$ Universitas Indonusa Esa Unggul, Jakarta, Indonesia \\ ${ }^{4}$ Universitas Prof Dr Moestopo (Beragama), Jakarta, Indonesia \\ *Corresponding author: rajab.ritonga@dsn.moestopo.ac.id
}

\begin{abstract}
The South China Sea is a vital body of water for regional and extra-regional countries. The rivalry between two major powers, namely China and the United States, the closer relations between the former and Russia in the past few years, in particular their joint naval exercise in the South China Sea in the second week of September 2016, and North Korea's latest nuclear test reflect the region's highly dynamic strategic environment that changes day by day. These dynamics eventually influence countries in the region, including Indonesia. It is therefore crucial for Indonesia to have a complete and thorough understanding on the dispute and its implications on regional maritime security as it paves its way to become the Global Maritime Fulcrum (GMF). Therefore, this paper presents Indonesia's perspective on the South China Sea dispute and regional maritime security. It includes China's island building and reclamation, the role of the China coast guard in the South China Sea dispute, and Philippines' case in Hague. Finally, implications for Indonesia and future agenda are presented.
\end{abstract}

Keywords: South China Sea; Dispute; Maritime; Security; Indonesia.

\section{Introduction}

In the $21^{\text {st }}$ century, the maritime remains the world's most vital domain as it dictates a state's geopolitics, geoeconomic, and geostrategic maneuvers [1]. The importance of the seas and oceans as routes for the shipping of goods, people, and energy remains. As countries depend more and more with one another, depleting sources of energy and food along with the role of non-state actors play in the international arena, the vast seas and oceans are even more vital to a country's survivability [2].

Such a notion is especially evident in Asia Pacific, a region where global economic and security center of gravity is currently located. In this region, in which some may expand the area more through the term Indo Pacific, is where Indonesia is located. As the world's archipelagic state, Indonesia is strategically located in the heart of the Asia Pacific and the Indo Pacific region as it connects both oceans and two continents. The oceans and seas bring both challenges and opportunities. The former include maritime disputes, and the region is the location of one of the most talked about disputes in the world; the South China Sea dispute between the six claimant states: Brunei, China, Malaysia, Philippines, Taiwan and Vietnam. The dispute has become not only news headlines all over the world, but also the center of discussion in many seminars, symposiums and even regional-level meetings and summits [3-6]. The South China Sea is a vital body of water for regional and extra-regional countries [7-9]. The rivalry between two major powers, namely China and the United States, the closer relations between the former and Russia in the past few years $[10,11]$. In particular their joint naval exercise in 
the South China Sea in the second week of September 2016, and North Korea's latest nuclear test reflect the region's highly dynamic strategic environment that changes day by day. These dynamics eventually influence countries in the region, including Indonesia. It is therefore crucial for Indonesia to have a complete and thorough understanding on the dispute and its implications on regional maritime security as it paves its way to become the Global Maritime Fulcrum (GMF).

Based on the above description, this paper presents Indonesia's perspective on the South China Sea dispute and regional maritime security. In summary, the contributions of this work are summarized as follow:

a. Maritime domain awareness and the global maritime fulcrum vision of Indonesia are presented.

b. China's island building and reclamation is presented.

c. The role of the China coast guard in the South China Sea dispute is presented

d. Philippines' case in Hague is discussed.

e. Implications for Indonesia are presented and future agenda are highlighted.

The rest of this paper is organized as follow; Section 2 presents martime of Indonesia. Section 3 presents main reults of this work on South China dispute. Section 4 presents the effect of South China dispute to Indonesia. Finally, Section 5 concludes this work.

\section{Indonesia, Maritime Domain Awareness and the Global Maritime Fulcrum Vision}

Indonesia is a country like no other. Its geographical characteristics and strategic positioning reflect a maritime nation. It has a long history at sea as well as an international acknowledgment of its status as an archipelagic state through the United Nations Convention on the Law of the Sea (UNCLOS 1982) [12]. For anyone to understand the vastness of Indonesia one should look at the map of the country. As can be seen in Figure 1, Indonesia is an archipelagic state with 17,499 islands, big and small, a coastline of 81,000 kilometers and waters of 5.9 million square kilometers.

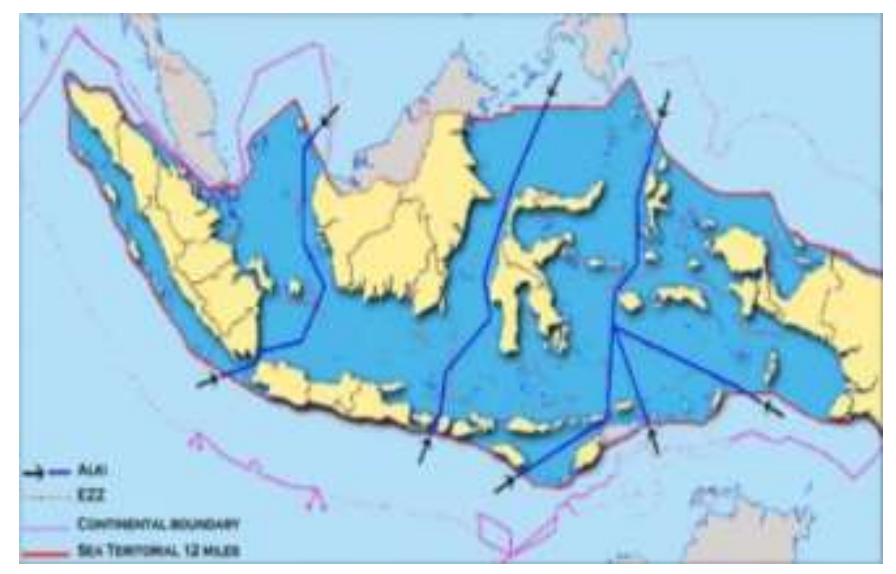

Figure 1. Indonesia's Geographical Characteristics

If compared to the map of the United States, Indonesia stretches perfectly covering the West and the East Coasts. Its strategic geographical location - situated between the Indian and Pacific Oceans and between the Asia and Australia continents as well as having its waters cover two third of Southeast Asia - poses both challenges and opportunities.

The UNCLOS 1982 provides Indonesia the international recognition of its status as an archipelagic state. The country's aspiration for global acknowledgement to the unity of its islands and waters, however, started 25 years prior through the Djuanda Declaration on 13 December 1957. The year after, United Nations' first conference on the law of the sea 
produced the world's first laws of the sea, regulating territorial seas, contiguous zone, continental shelf and the high seas. These conventions became the basis of Indonesia's negotiations and struggle for its archipelagic status. Understanding these maritime regimes, presented in Figure 2, is crucial in determining how a country formulates its maritime-related policies.

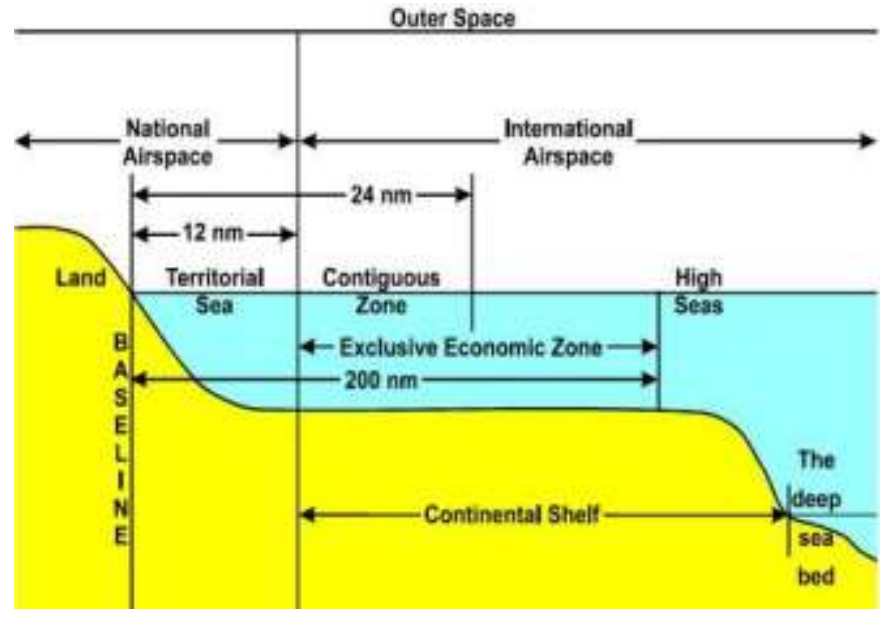

Figure 2. Maritime Zones under UNCLOS 1982

Indonesia's strategic geographical characteristics and location pose both opportunities and challenges. In order to manage both benefits and threats, Indonesia develops its Maritime Domain Awareness (MDA) according to United Nations Conference on the Law of the Sea, held in Geneva from 24 February to 27 April 1958 [13], a concept first coined by the United States in its National Plan to Achieve Maritime Domain Awareness, published in 2005.

In this 21st century, Asia Pacific has seen more maritime-related issues rising as the region's main security issues. Being the world's largest archipelagic state and situated strategically in the center of the region, it is only natural for Indonesia to implement MDA. Four of the world's nine strategic choke points are located in Indonesia. Its three archipelagic sea lanes provide global shipping with easy access to the Indian and Pacific oceans as well as to East Asia and Australia.

For Indonesia, MDA is a national system that involves each and every national maritime stakeholder under the coordination of the government. The role of the government is crucial to emphasize the importance of a single body, legitimized under national and international law to be responsible for managing illegal activities at sea.

Today, as the world's center of gravity has shifted from the West to Asia, the desire to rekindle Indonesia's maritime spirit is very much strong. This aspiration is manifested in the Global Maritime Fulcrum (GMF) concept and supported by the Five Maritime Pillars, which are; (1) rebuild Indonesia's maritime culture, (2) maintain and manage marine resources, with a focus on building marine food sovereignty through the development of the fishing industry, (3) provide priority to the development of maritime infrastructure and connectivity by constructing sea highways along the shore of Java, establish deep seaports and logistical networks as well as developing the shipping industry and maritime tourism, (4) through maritime diplomacy, Indonesia invites other nations to cooperate in the marine field and eliminate the source of conflicts at sea, including illegal fishing, territorial disputes and marine pollution, and (5) development of maritime defense forces [14]. This concept is the foundation of Indonesia's national development. President Joko Widodo announced the GMF concept and its pillars during the 2014 East Asia Summit (EAS) in Napyidaw, Myanmar. 


\section{The South China Sea Dispute}

The seas and oceans present both challenges and opportunities. This notion bods well with Indonesia, the biggest country with the largest body of water in Southeast Asia. As a maritime region, maritime boundary delimitation is crucial for the Southeast Asia region. Since the countries in the region are mostly coastal or archipelagic states and the waters of the region are governed by territorial seas and exclusive economic zones, overlapping of claims is inevitable [15]. Indonesia understands this issue very well since. Figure 3 shows that Indonesia has maritime boundaries with ten countries, spanning across the Indian Ocean, the South China Sea and the Pacific Ocean. These 10 countries are, in alphabetical order: Australia, India, Malaysia, Palau, Papua Nugini, the Philippines, Singapore, Thailand, Timor Leste and Vietnam.

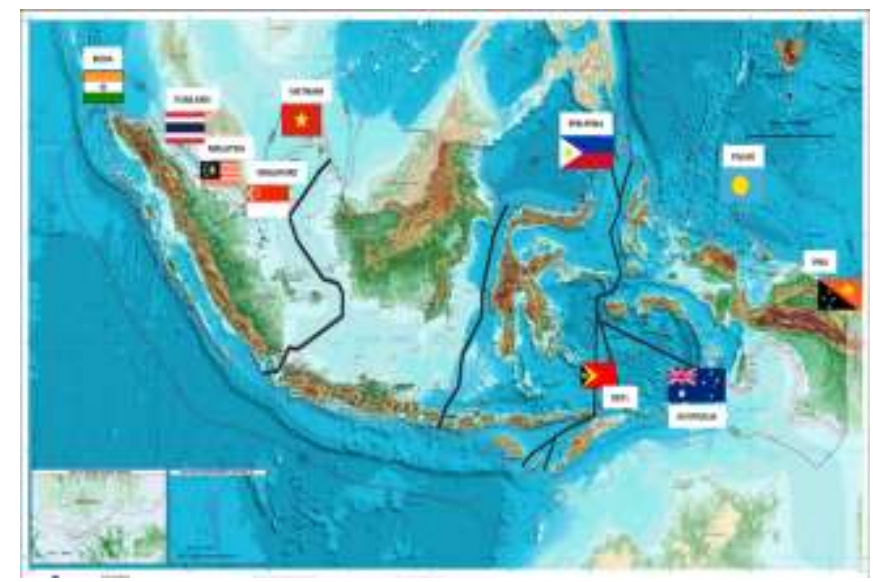

Figure 3. Indonesia's Maritime Boundary Delimitations

Most of these maritime boundaries are yet to be agreed with the respective countries, although there are positive developments with Singapore. For example until 2014, Indonesia and Singapore have agreed upon three out of four areas of maritime boundaries [16]. The last one was signed on September $3^{\text {rd }}, 2014$ [16]. The complex natures of maritime disputes are very well exemplified by the South China Sea case. The area in dispute at least around 1.3 million square miles claimed by China [17], which are stretches from Singapore and the Malacca Strait to the Taiwan Strait. Not only is it number six of the world's largest body of water [18], the South China Sea's role in determining regional strategic balance eventually influences global order since (1) it is a crucial shipping traffic for trade and energy, and (2) rich in natural marine resources, making it an area of resource competition [19].

Each of the six claimants of the South China Sea dispute has presented its respective reasoning for either claiming the islands of Paracel and Spratly or the rights of the exclusive economic zone in the waters (See Figure 4). 


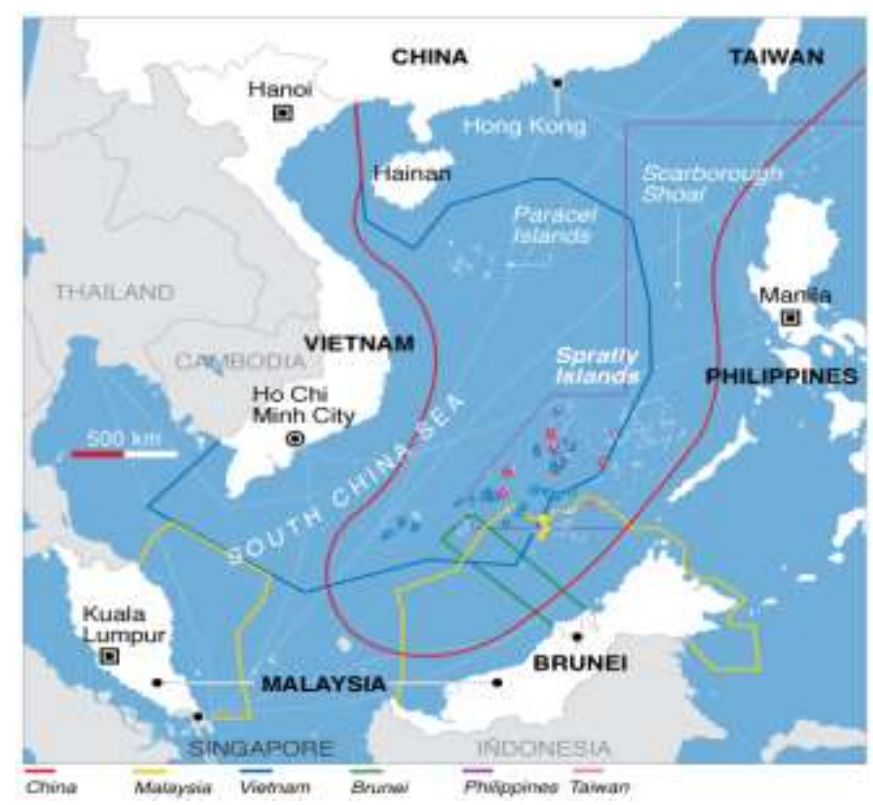

Figure 4. The South China Sea Dispute

Some even have their own names for the South China Sea e.g. China calls it the South Sea, Vietnam named it the East Sea and the Philippines stated it as the West Philippine Sea. The issue is not new to the Asia Pacific region; however, it rose back to the international limelight after the Scarborough Shoal incident in 2012 between China and the Philippines. In early April 2012, Philippine Navy spotted a number of Chinese fishing vessels near the Scarborough Shoal and sent its warship to board the vessels. Not long after that Beijing sent its two maritime surveillance ships, which then came in between Philippine Navy's Gregorio del Pilar and the fishing vessels to prevent any kind of arrest due to illegal fishing charges. This incident started months of standoff between these claimant states. It is fair to say that since this incident, all eyes are set in the region and many defense analysts and academics have expressed their concern that tensions in the South China Sea may bring the region to the brink of an armed conflict.

\section{A. China's Island Building and Reclamation}

China's active building and reclamation in the rocks and reefs of the Spratlys Islands have received strong reactions from both claimant and non-claimant states. Satellite images of the reefs in the Spratlys Islands, where the satellite images are available at [20] show massive construction efforts on the reefs, resulting in buildings, facilities and even airstrips capable for civil and military aircraft landings and take-offs. Figure 5 shows the significant difference of China's airstrip in the Fiery Cross Reef compared to the others built by other claimant states in the area. Since January 2016, China has landed civilian and military aircraft multiple times in the Fiery Cross Reef, As early as 2 January 2016 China's civil aircraft landed in the Fiery Cross Reef [21]. In April 2016, a military jet landed in the same airstrip for emergency reasons [22] and the activities continue even after the Hague-ruling in July of 2016 [23]. This to amid the protests of both claimant and non-claimant states such as Philippines, Vietnam and the United States [24].

China has defended its actions by claiming it is building shelters and aids for navigation as well as for search and rescue due to the threat of typhoon in the region. Chinese Foreign Ministry spokeswoman Hua Chunying briefed the media on 9 April 2015 that all the constructions are "entirely within the scope of China's sovereignty. It is fair, reasonable, and lawful, where it does not affect and is not targeted against any country and it is beyond reproach [25]. 


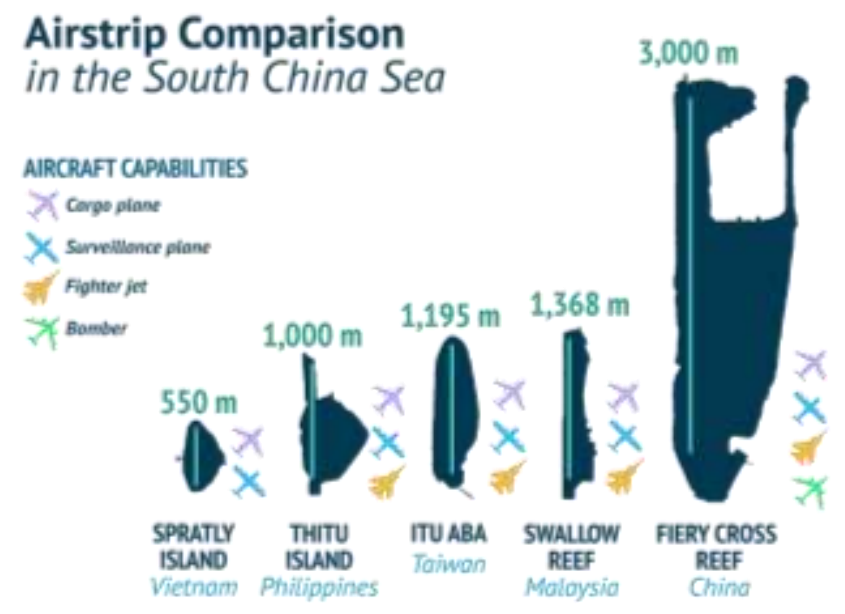

\section{Figure 5. Airstrip Comparison in the South China Sea [26]}

It is important to note that China is not the only and, indeed, not the first one to undergo construction and reclamation activities in the islands and reefs in the South China Sea. However, the scale it is making in the Spratly Islands is staggering compared to other claimant states' developments. Malaysia, for example, has taken on reclamation at Swallow Reef since the 1980s, expanding it from 25 to 85 acres and constructed an airstrip, a resort and a small naval base [27]. Vietnam, on the other hand, is estimated to have added around 65,000 square meters to West Reef and 21,000 square meters to Sand Cay, both in the Spratly Islands. For further information on Vietnam's construction and reclamation process in both areas, including satellite images of developments [28]. China, on the other hand, expanded Fiery Cross Reef more than 2.7 million square meters, including an airstrip and a 630.000 square-meter harbor [29]. To see more of China's development in Fiery Cross Reef and other six areas in the Spratly Islands [30].

\section{B. $\quad$ The Role of the China Coast Guard in the South China Sea Dispute}

China has played an impressive tactic as it exerts its influence and maintains its national interest in the South China Sea. It understands the implications of deploying its naval ships to face vessels of claimant states in the disputed waters or other body of water where it has significant maritime interest. Hence, China utilizes its non-military maritime forces, namely China Coast Guard (CCG) and its maritime militia.

CCG was established in 2013, just a year after China's commitment to become a maritime power. This maritime body is the result of the merging of four out of the five major maritime administrative agencies in China, which are China Marine Surveillance (CMS), China Fisheries Law Enforcement (CFLE), Maritime Police and Border Control (MPBC), and Maritime Anti-Smuggling Police (MASP). The fifth maritime agency, the Maritime Safety Administration, is part of the Ministry of Transport.

Since its establishment, the CCG has played an important role in securing China's maritime interest. According to the Center for Strategic \& International Studies (CSIS) in Washington D.C., CCG vessels were involved in 68 percent of major maritime incidents in the South China Sea in between 2010 and 2016, where Out of the 45 major incidents recorded by CSIS, four involved a ship from the Chinese Navy. This raises the number of involvement by Chinese maritime forces to 78 percent [31]. This number is significant and raises the question of the nature of the CCG as China's civilian maritime agency at sea. Further reports indicate such a trend may rise in the future. CSIS stated that China, quoting a forthcoming Naval War College Review article, has an average annual budget 
of $\$ 1.74$ billion for CCG in the past five years [32]. The U.S. Navy's Office of Naval Intelligence reported CCG to have 205 vessels, making it the largest coast guard fleet in the world [33]. Figure 6 shows a comparison of coast guard vessel tonnage of China, Japan and a number of ASEAN countries, including Indonesia.

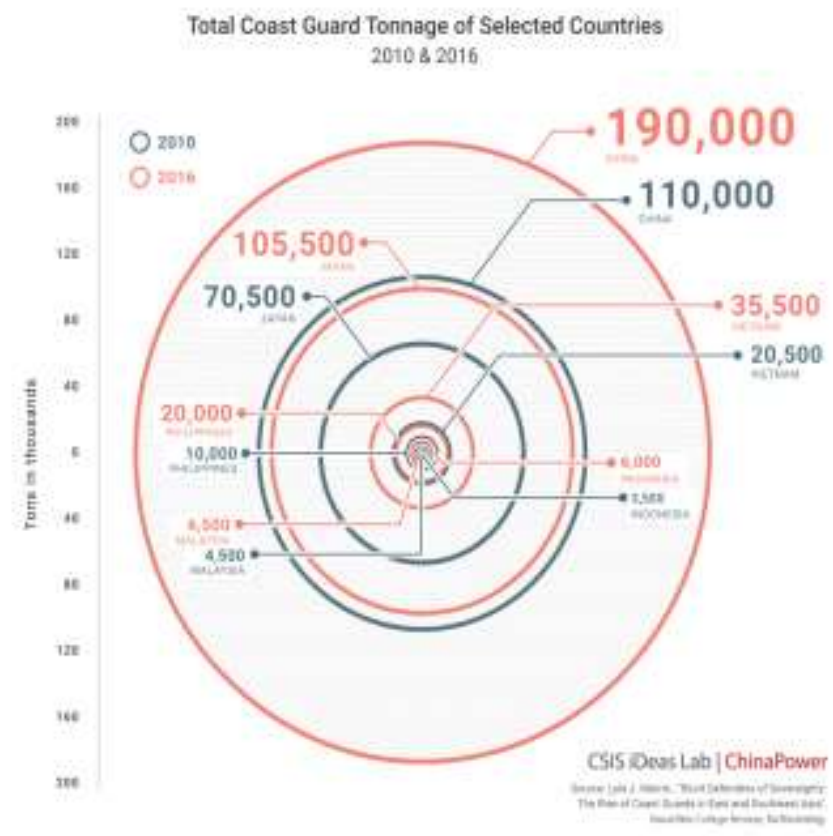

Figure 6. CSIS' Total Coast Guard Tonnage of Selected Countries [33]

Indonesia's maritime forces have encountered CCG vessels in incidents related to maritime fishing rights many times in the past for some years, particularly in Indonesia's Exclusive Economic Zone (EEZ) near the Natuna Islands, adjacent to the South China Sea. The first incident occurred a year after China presented its infamous nine-dash line map to the United Nations. On 23 June 2010 an Indonesian warship detected two Chinese Fishery Law Enforcement vessels guarding a Chinese fishing boat on Indonesia's EEZ. In 2012, a CCG vessel attempted shadowing an Indonesian warship that captured a Chinese fishing vessel. On 22 June 2015 a Chinese fishing vessel was caught fishing in Indonesia's EEZ without legal documents. In this incident, a CCG vessel once again attempted shadowing maneuver to release the fishing boat.

In 2016 around three incidents occurred. The first incident of 2016 happened in March 2016 in which a CCG vessel rammed a Chinese fishing vessel in order to avoid Indonesian authorities to take the ship back to port for legal processing [34,35]. In May 2016, the second incident happened where an Indonesian warship captured a Chinese fishing vessel in the same area, the Gui Bei Yu. The warship, KRI Oswald Siahaan-354, also managed to block a CCG vessel intending to rescue the captured fishing vessel [36]. The June 2016 incident, which also involved an Indonesian warship and a CCG vessel [37], was then followed by a presidential visit by President Joko Widodo to the Natuna Islands 23 June 2016 as well as a special cabinet meeting onboard an Indonesian warship, sending a strong message to China on Indonesia's commitment to its sovereignty and sovereign rights [38] as well as China's claims that Indonesia's EEZ is China's "traditional fishing grounds", where Indonesia does not acknowledge the term "traditional fishing ground" as it is regulated within the UNCLOS 1982. The international sea convention has its own articles on traditional fishing zone but it must be agreed. 


\section{Philippines' Case in The Hague}

Some have warned that China's continuous aggressiveness in facing other claimant states in the South China Sea would cause some restrain in terms of its friendship with these countries residing in Southeast Asia [39]. In fact, it may be the very reason why the Philippines has taken China's claims to the Permanent Court of Arbitration [40] as the registry for the UNCLOS-based arbitration. The Philippines presented its case on 22 January 2013 [41], raising five points against China's claims in the South China Sea, which are "China is not entitled to exercise "historic rights" over the region, China's nine dash line has no international legal basis, China's claims are to geographical bodies which under international law do not confer EEZ zones, China has violated the sovereign right and jurisdiction of the Philippines, and finally, China has violated UNCLOS by damaging the regional marine environment [42]."

Beijing has tried to bring back the Philippines to the bilateral negotiation table. Manila, however, has stated that it would not withdraw its arbitration case [43], despite some "threats' made within Chinese media that China could reclaim South China Sea from the Philippines by "force" [44]. Many have expressed their admiration to the Philippines' boldness in challenging China through international law, since it is the first country to be so very brave to take such action upon the rising giant [45].

The tribunal of arbiters constituted under Annex VII of UNCLOS 1982 finally announced their unanimous ruling on 12 July 2016, denying China any legal basis to its historical claims in the South China Sea [46]. Not only that, the tribunal also found China violating Philippines' sovereign rights in its EEZ [47]. The Philippine side obviously received the award well, although there were no frantic celebration smade, and China's reaction to refuse abiding to such ruling is not new [48] as it has continuously expressed by its spokesperson of related agencies [49]. Its Foreign Ministry was even quoted to state that China "solemnly declares that the award is null and void and has no binding force [50]."

Although the arbitration ruling was very clear in terms of China's claims in the South China, it does not have legal binding mechanisms that could force China to abide the rulings. In fact, China continues business as usual and could even influence on how meetings of countries and regional organizations formulate their statements on the ruling itself.

This was evident in the recent ASEAN Summit meeting in Vientiane, Laos of September 2016. Even though U.S. President Barack Obama pushed the issue of the South China Sea dispute and the arbitration ruling in the meeting [51] with the help of Japan, China was able to have the ASEAN statement to omit any mention of the tribunal ruling, all thanks to the "ASEAN Way" [52]. Still, the South China Sea dispute remains to overshadow many regional meetings [53].

During the $15^{\text {th }}$ Shangri-La Dialogue in early June 2016, it was impossible to avoid the South China Sea as one of the most talked about topics in the regional security summit. Most of the panelists who are defense ministers of regional countries in Asia Pacific would mention the South China Sea dispute as one of the main regional challenges. Questions would be addressed regarding the issue as well as the upcoming tribunal ruling at that time [54]. Admiral Sun Jianguo, Deputy Chief, Joint Staff Department, Central Military Commission, said that "China's South China Sea policy has not and cannot change. China has the wisdom and patience to resolve the dispute through peaceful negotiation, and believes that the other countries involved have the wisdom and patience to collaboratively come over to this peaceful path, and countries who aren't involved should not try to destroy the path we walk in order to benefit their own selfish interests [55]." 


\section{Implications for Indonesia}

Indonesia is not one of the claimant states of the South China Sea dispute, but having its waters very close to the disputed area, whatever the future of the dispute may be, it will eventually have consequences upon various sectors. In fact Indonesia has already predicted that the South China Sea would become one of the region's flashpoint since 1990, when it hosted the Workshop for Managing Potential Conflict in the South China Sea in Bali [56]. The goal was to establish confidence building measures (CBM) among countries with interests upon the waters [57]. The workshop continued to run until 2002. In short, Indonesia has concrete interests in the South China Sea. If the dispute escalated into armed conflict at sea, it would have grave implication to regional peace and stability. Politically, it would place Indonesia in a difficult position, being in between two major powers; China and the United States [58]. On the other hand, China's U-shaped nine dash line, submitted to the United Nations in 2009 [58], clearly includes Indonesia's Exclusive Economic Zone (EEZ), which is one of the reasons Indonesia has taken an active role in the settlement of this dispute [59]. Indonesia wants to prevent this spill over since it would influence the country's economy since there are abundant energy resources in the EEZ. Another economic concern is the possible rise of insurance fee for ships sailing across the region and a change of route of merchant ships, causing Indonesia to have significant revenue lose [60].

For its defense and security sectors, an extreme escalation of conflict in the South China Sea would push Indonesia, as well as other countries in the region, claimants and non-claimants, to strengthen their military power, particularly naval forces. This has been discussed by analysts since the 1990s [61] and is especially a hot topic in the $21^{\text {st }}$ century [61]. There has been steady and significant rise in Asia's defense spending, where one report estimated it has increased 27 percent between 2010 and 2014, mostly focused on naval and air force procurements [62]. In 2012, Asia defeated the defense budget of NATO's member from the European continent [63]. At a time where global military spending continues to fall since 2012, Asia's (and Oceania) continues to rise, reaching 5 percent in 2014 worth $\$ 439$ billion [63]. For Indonesia, it will increase its defense spending until $\$ 15$ billion by 2020 [64] in the midst of the region's dynamic security environment and the tensions in South China Sea. It is evident that Southeast Asian countries are acquiring more lethal naval and coast guard weaponries, which at the same time increases the risk of lethal confrontation [65]. Therefore, this creates more issues than that solving those problems. Figure 7 as following presents Indonesia's Defense Spending during the period of 2010-2019.

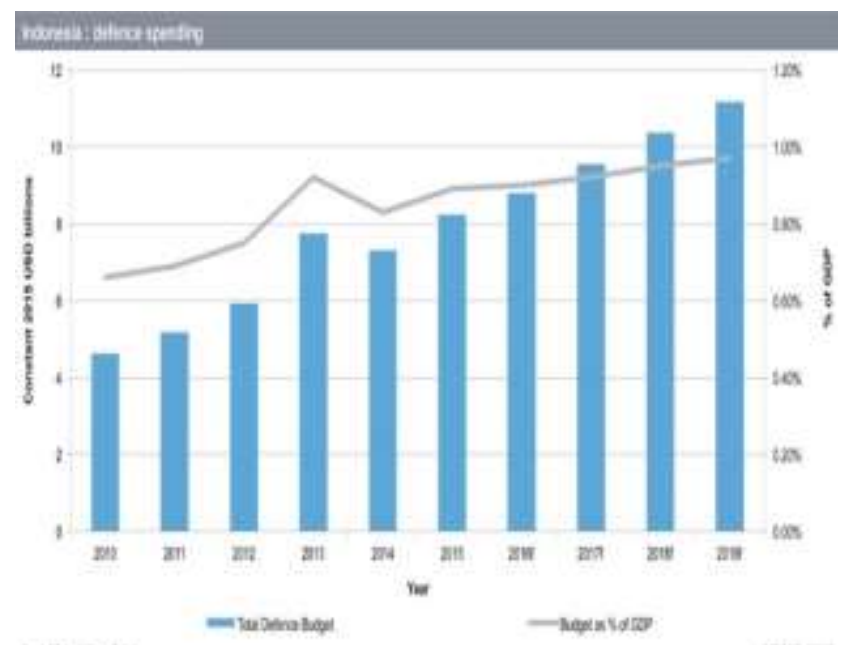

Figure 7. Indonesia's Defense Spending 2010-2019 [66] 


\section{A. What has Indonesia done and what's next?}

A peaceful and stable South China Sea is important for Indonesia and for long it has been committed in supporting peaceful settlement of the dispute. Besides hosting the Workshop for Managing Potential Conflict in the South China Sea as mentioned previously, Indonesia has taken an active role in promoting negotiations and talks as well as developing understanding among claimant and non-claimant states in the region, both bilaterally and multilaterally, the latter through the ASEAN frameworks. In regards to the formulation of the $\mathrm{CoC}$ for South China Sea, Indonesia presented the zero draft to the ASEAN foreign ministers in 2012 [67], which received immediate support from Singapore [68]. The current administration has also stated its commitment to support the South China Sea dispute settlement in peaceful ways [69].

Regional peace and stability is one of Indonesia's national interests and the country's commitment is very clear. It is important for Indonesia to do its part in ensuring the peaceful settlement of maritime boundary disputes in the region, including its own and the South China Sea. Therefore, Indonesia, in this case the Indonesian Navy, presented its new initiative by hosting a maritime security symposium that brings together the chiefs of naval and sea services of Western Pacific Naval Symposium (WPNS) and Indian Ocean Naval Symposium (IONS) to share experiences, best practices and new ideas on the topic. On a more practical level, Indonesia is the host of Asia Pacific's non-warfighting multilateral exercise code named Multilateral Naval Exercise Komodo. In 2016 this biennial exercise focused on maritime peacekeeping operations. During the same time, Indonesia will also host the International Fleet Review 2016 and the $15^{\text {th }}$ Western Pacific Naval Symposium.

As Indonesia pushes its Global Maritime Axis strategy through the development of the strategy's five pillars, it would need to have a clear plan on how it would step in supporting peaceful dispute settlement in the South China Sea and at the same time protect its interests. Since the dispute also entails the interests of other major powers, both in the region and beyond, with who Indonesia also have robust relations and bilateral cooperation, such a plan would ensure that Indonesia stays in its foreign policy path, free and active, while adhering to its role in the region and ensuring the respect and understanding of all related parties.

In terms of the tribunal ruling of Philippines' case against China in the South China Sea dispute, Indonesia urged all involved parties to the dispute to "respect applicable international laws" and to exercise self-restraint and to refrain from any actions that could escalate tensions, as well as to protect Southeast Asia region particularly from any military activity that could pose a threat to peace and stability, and to respect international law including UNCLOS 1982“ [70]. For Indonesia, a peaceful South China Sea plays a role in realizing a stable and prosperous region.

\section{Conclusion}

As an archipelagic state, Indonesia understands the importance of sovereignty upon the waters of a nation. Its past experience on maritime dispute settlement has become a lesson learned for current and future dispute settlement process. The issue of the South China Sea disputes clearly reflects how maritime dispute may have implications upon the region. This paper has presented Indonesia's perspective on the South China Sea dispute and regional maritime security. With its Global Maritime Axis strategy and its development of Maritime Domain Awareness, it is clear that regional maritime disputes are eminent challenges to Indonesia's path to realize itself as a maritime nation.

In the face of rising tensions, reclamations and strong statements, dialogues and discussions are still in play. As a non-claimant state to the South China Sea dispute, Indonesia affirms its commitment and role to promote peaceful dispute settlements and push forward forums for discussions and dialogue by hosting international-level 
conferences and exercise. It is also keen to propose future cooperation among claimant and non-claimant states in the South China Sea as means of reducing tensions. Committed fully to all efforts for a peaceful and prosperous region, Indonesia is active in numerous cooperation and initiatives, both bilateral and multilateral. Because whatever happens in the South China Sea, it would has immediate impact upon Indonesia's interests.

\section{Acknowledgement}

This research is supported by Indonesia Defense University research funding.

\section{References}

[1] Buurman, J., Zhang, S. and Babovic, V., 2009. Reducing risk through real options in systems design: the case of architecting a maritime domain protection system. Risk analysis, 29(3), pp. 366-379.

[2] Storey, I., 2009. Maritime Security in Southeast Asia: Two Cheers for Regional Cooperation. Southeast Asian Affairs, 2009(1), pp.36-58.

[3] Storey, I.J., 1999. Creeping Assertiveness: China, the Philippines and the South China Sea Dispute. Contemporary Southeast Asia, pp. 95-118.

[4] Guan, A.C., 2000. The South China Sea Dispute Revisited. Australian Journal of International Affairs, 54(2), pp.201-215.

[5] Buszynski, L., 2012. The South China Sea: oil, maritime claims, and US-China strategic rivalry. The Washington Quarterly, 35(2), pp.139-156.

[6] Rowan, J.P., 2005. The US-Japan security alliance, ASEAN, and the South China Sea dispute. Asian Survey, 45(3), pp.414-436.

[7] Hong, Z., 2013. The South China sea dispute and China-ASEAN relations. Asian Affairs, 44(1), pp.2743.

[8] Mincai, Y., 2014. China's Responses to the Compulsory Arbitration on the South China Sea Dispute: Legal Effects and Policy Options. Ocean Development \& International Law, 45(1), pp.1-16.

[9] Chan, I. and Li, M., 2015. New Chinese Leadership, New Policy in the South China Sea Dispute?. Journal of Chinese Political Science, 20(1), pp.35-50.

[10] McDevitt, M., 2015. The South China Sea: Assessing US Policy. American Foreign Policy Interests, 37(1), pp.23-30.

[11] Fravel, T., 2016. US Policy Towards the Disputes in the South China Sea Since 1995. In Power Politics in Asia's Contested Waters (pp. 389-402). Springer International Publishing.

[12] www.un.org/depts/los/convention_agreements/texts/unclos/UNCLOS-TOC.htm

[13] http://legal.un.org/avl/ha/gclos/gclos.html

[14] http://www.thejakartapost.com/news/2014/11/13/jokowi-launches-maritime-doctrineworld.html\#sthash.Ua91EBhL.dpuf

[15] T. Davenport, Southeast Asia Approaches to Maritime Delimitation, an AsianSIL Working Paper2012/7, presented at 3rd NUS-AsianSIL Young Scholars Workshop, NUS Law School, 23-24 February 2012, p. 1,

[16] http://thejakartaglobe.beritasatu.com/news/indonesia-singapore-agree-border-batam-island-changi/

[17] http://www.straitstimes.com/news/asia/south-east-asia/story/singapore-indonesia-sign-treatydemarcating-maritime-boundaries-2014

[18] A. Singh, South China Sea Dispute: Regional Issue, Global Concern, Maritime Affairs, Journal of the National Maritime Foundation of India, 8:1, 2012, p. 117-118

[19] A. Patalano, Maritime Strategy in the South China Sea in Daniel Moran and James A. Russell (Ed.),

[20] http://amti.csis.org/island-tracker/

[21] http://www.bbc.com/news/world-asia-china-35249092.

[22] http://edition.cnn.com/2016/04/18/politics/chinese-military-jet-lands-on-island/

[23] http://uk.reuters.com/article/uk-southchinasea-ruling-airport-idUKKCNOZT0Z4

[24] http://thediplomat.com/2016/01/vietnam-protests-as-china-lands-civilian-aircraft-on-newly-constructedspratly-airstrip/

[25] http://www.reuters.com/article/2015/04/09/china-southchinasea-reef-idUSL4N0X62Q020150409

[26] https://amti.csis.org/airstrips-scs/

[27] Gregory Poling, Sophistry and Bad Messaging in the South China Sea, 1 July 2015, available at

[28] http://amti.csis.org/sophistry-and-bad-messaging-in-the-south-china-sea/

[29] http://amti.csis.org/vietnam-island-building/

[30] http://amti.csis.org/island-tracker/

[31] http://chinapower.csis.org/maritime-forces-destabilizing-asia/\#card2

[32] http://www.thejakartapost.com/news/2016/03/21/ri-confronts-china-fishing.html ।

[33] http://thediplomat.com/2016/03/indonesia-summons-chinese-ambassador-after-south-china-sea-standoff-near-natuna-islands/ 
[34] http://chinapower.csis.org/maritime-forces-destabilizing-asia/\#card2

[35] http://www.thejakartapost.com/news/2016/05/30/fresh-natuna-incident-roils-ri-china-relations.html

[36] http://thediplomat.com/2016/06/a-third-2016-natuna-stand-off-highlights-growing-indonesia-chinatensions/

[37] http://www.reuters.com/article/us-southchinasea-indonesia-idUSKCN0Z909D

[38] http://amti.csis.org/china-may-lose-friends-in-southeast-asia/

[39] http://amti.csis.org/arbitration-101-philippines-v-china/

[40] http://www.pcacases.com/web/view/7

[41] http://www.valuewalk.com/2015/07/philippines-vs-china-the-case-of-south-china-sea/

[42] http://www.philstar.com/headlines/2015/07/24/1480386/philippines-wont-withdraw-arbitration-case-vschina

[43] http://www.ibtimes.com/retired-general-says-china-could-reclaim-disputed-south-china-sea-reefphilippines-2017354

[44] http://www.huffingtonpost.com/richard-javad-heydarian/china-vs-the-philippines-_b_7766406.htm

[45] https://pca-cpa.org/en/news/pca-press-release-the-south-china-sea-arbitration-the-republic-of-thephilippines-v-the-peoples-republic-of-china/

[46] http://globalnation.inquirer.net/140358/philippines-arbitration-decision-maritime-dispute-south-chinasea-arbitral-tribunal-unclos-itlos

[47] http://www.reuters.com/article/us-china-philippines-court-idUSKCNOZF1QV

[48] https://amti.csis.org/ArbitrationTL/

[49] https://www.washingtonpost.com/world/beijing-remains-angry-defiant-and-defensive-as-key-southchina-sea-tribunal-ruling-looms/2016/07/12/11100f48-4771-11e6-8dac-0c6e4accc5b1_story.html

[50] http://hosted2.ap.org/APDEFAULT/3d281c11a96b4ad082fe88aa0db04305/Article_2016-09-08-AS-Southeast\%20Asia-South\%20China\%20Sea/id-98a7ddddccd24f1aa34e0e81897d0c68

[51] "Cara ASEAN" Menyelamatkan Naga (The ASEAN Way Saved the Dragon), 11 September 2016, Kompas daily newspaper, print edition.

[52] http://www.aljazeera.com/news/2016/09/south-china-sea-row-tops-asean-summit-agenda160908052213165.html

[53] https://www.iiss.org/en/events/shangri\%20la\%20dialogue/archive/shangri-la-dialogue-2016-4a4b

[54] https://www.iiss.org/en/events/shangri\%201a\%20dialogue/archive/shangri-la-dialogue-20164a4b/plenary4-6c15/jianguo-6391

[55] http://ikal.or.id/index.php/pengaruh-keamanan-regional-bagi-keamanan-nasional-indonesia-kasussengketa-laut-cina-selatan.html

[56] http://www.cfr.org/china/south-china-sea-tensions/p29790, was accessed on 20 July 2015

[57] https://www.dur.ac.uk/resources/ibru/publications/full/bsb2-2_schofield.pdf

[58] http://www.cnbc.com/2015/05/21/asia-defense-spending-new-arms-race-in-south-china- sea.html,

[59] http://thediplomat.com/2015/01/explaining-southeast-asias-force-buildup/

[60] http://www.reuters.com/article/2015/05/26/us-southchinasea-maritime-buildupidUSKBN0OA1JD20150526

[61] Military Balance 2015, the International Institute for Strategic Studies, p. 7

[62] Bill Hayton, The South China Sea: The Struggle for Power in Asia, (Yale University Press, 2014), p. 234

[63] http://www.sipri.org/media/pressreleases/2015/milex-april-2015

[64] http://www.janes.com/article/51041/indonesia-commits-to-ambitious-defence-budget-increase

[65] http://www.reuters.com/article/2015/05/26/us-southchinasea-maritime-buildupidUSKBN0OA1JD20150526

[66] http://www.janes.com/article/51041/indonesia-commits-to-ambitious-defence-budget-increase

[67] http://nbr.org/research/activity.aspx?id=360

[68] http://www.thejakartapost.com/news/2012/10/25/singapore-supports-ri-s-draft-settle-s-china-seadispute.html\#sthash.cMe3qFGR.dpuf

[69] http://jateng.metrotvnews.com/read/2015/05/31/400842/indonesia-siap-damaikan-konflik-di-laut-cinaselatan

[70] http://www.thejakartapost.com/seasia/2016/07/12/indonesia-urges-parties-to-respect-laws-followingsouth-china-sea-ruling.html 